\title{
EXPRESSION OF ARGYROPHILIC NUCLEOLAR ORGANIZING REGION COUNTS AND PROLIFERATING CELL NUCLEAR ANTIGEN IN EPITHELIAL ODONTOGENIC TUMORS
}

\author{
Amr A. Mohamed ${ }^{1} B D S$, Zeinab E. Darwish ${ }^{2} P h D$, Sahar M. Elsheikh² $P h D$, Ibrahim M.
}

\author{
Zeitoun ${ }^{3} P h D$.
}

\begin{abstract}
INTRODUCTION: Odontogenic tumors are diverse groups of lesions derived from odontogenic tissues. Clinical behavior of these lesions varies widely, ranging from benign to malignant with differences in recurrence rate and growth pattern. A better understanding of the underlying molecular mechanisms will help to predict the course of odontogenic tumors and lead to the development of new therapeutic applications. Nucleolar organizer regions (NORs) are loops of DNA that codify the ribosomal RNA and are considered important for protein synthesis. The NORs stained histochemicaly by silver are named argyrophilic nucleolar organizer regions (AgNOR). Quantification of AgNOR represents a valuable parameter of cell kinetics and therefore cell proliferation. The number of AgNOR sites in malignant cells is significantly greater than those in their normal or benign counterparts. Proliferating cell nuclear antigen (PCNA) is a useful marker of cellular proliferation and DNA replication. Malignant tissue is characterized by an uncoordinated proliferating cell nuclear antigen (PCNA).

OBJECTIVES: To evaluate the cell proliferation rate using the expression of Argyrophilic Organizing Region counts and Proliferating Cell Nuclear Antigen in epithelial odontogenic tumors and to assess the usefulness of AgNOR and PCNA as markers in malignant potential of epithelial odontogenic tumors.

MATERIALS AND METHODS: This study was done on 45 surgical specimens of epithelial odontogenic tumors and one control specimen from normal tooth germ. The tissue biopsies were processed and paraffin sections were prepared. Hematoxylin and eosin-stained sections were examined for diagnosis. Other sections were subjected to AgNORhistochemical technique and immunohistochemical staining for PCNA. Immunohistochemical staining was performed using a Labeled Strept-Avidin Biotin complex method (LSAB).

RESULTS: The mean AgNOR count of tooth germ was 1.21 and the benign odontogenic tumors was 1.862.The highest AgNOR count was recorded in Ameloblastic carcinoma and lowest was seen in adenomatoid odontogenic tumor. Statistically significant difference in AgNOR counts of ameloblastoma and adenomatoid odontogenic tumor, ameloblastoma and calcifying epithelial odontogenic tumor, benign odontogenic tumors and ameloblastic carcinoma were seen. AgNORs in ameloblastic carcinoma were more in number and more widely distributed.The highest mean value of PCNA-positive cell percentage was demonstrated in ameloblastic carcinoma followed by ameloblastoma. A significant difference was noted when the PCNA value of ameloblastoma was compared with that of ameloblastic carcinoma.

CONCLUSIONS: AgNOR technique may be considered a good indicator of cell proliferation in epithelial odontogenic tumors.The PCNA expression, along with the clinical features, can predict the aggressiveness, chances of recurrence and malignant potential of these tumors.

KEYWORDS: Odontogenic tumors, Argyrophilic nucleolar organizer regions, Proliferating cell nuclear antigen.
\end{abstract}

1-Instructor at Oral Pathology Department, Faculty of Oral and Dental Medicine, South Valley University.

2-Professor Oral Pathology Department, Faculty of Dentistry, Alexandria University.

3-Professor Cranio Maxillofacial and Plastic Surgery, Faculty of Dentistry, Alexandria University.

Corresponding author:

E-mail: amrabdelmoez2002@gmail.com

\section{INTRODUCTION}

Odontogenic tumors (OTs) are a large group of jaw tumors arising from Odontogenic apparatus during or after odontogenesis. Histopathologically, they vary in behavior from hamartomatous-like lesions to benign and malignant lesions. They may arise from epithelium or ectomesenchyme or both which are a part of the tooth forming apparatus. They may occur centrally within the jaw bones or the gingival mucosa (peripheral). The majority of Odontogenic tumors are benign; however, some, typically (but not exclusively) ameloblastomas, show locally infiltrative behavior while Ameloblastic carcinoma is the malignant counterpart of ameloblastoma, presenting an ameloblastic epithelium with malignant characteristics (1$3)$. Better understanding of the clinical and biological characteristics of these OTs can be useful for diagnosis, classification, and treatment. Interest has been focused on seeking reliable guide for prognosis, by measuring cell proliferation and correlating this data with the potential for metastasis and recurrence (4).

Nucleolar organizer regions (NORs) are loops of DNA that transcribe for ribosomal RNA (rRNA).Associated with these regions are certain acidic and argyrophilic, nonhistonic proteins called NOR-associated proteins (NORAPs). NORs can be demonstrated in tissue sections by staining their associated proteins with colloidal silver and these silver-stained reaction products represent the argyrophilic nucleolar organizer regions (AgNORs) $(5,6)$. The NORs reflect protein synthesis and are known to increase in number during malignancies. Several studies have shown that AgNOR counts can be used to differentiate between benign and malignant lesions (7-10). This technique plays a major role in estimating the proliferation potential of neoplasms in the surgical pathological practice 
(11-15). However, there are only a few studies of AgNOR counts in odontogenic tumors $(16,17)$.

Proliferating cell nuclear antigen, an essential regulator of the cell cycle, is highly conserved among species.It is an evolutionally well-conserved protein and found in all eukaryotic species from yeast to humans. Its functions are related to vital cellular processes such as DNA replication, chromatin remodeling, DNA repair, sister chromatid cohesion, and cell cycle control $(18,19)$.

Functional alterations in PCNA activity are common genetic events in various types of cancers and have been found to be effective markers of cell proliferation, which can be used as an independent predictor of histological grade, recurrence rate, and prognosis $(20,21)$. A previous study has shown that it can be used as an indicator of the malignant potential of oral lesions (22).

The aim of the present work wasto evaluate the cell proliferation rate using the expression of Argyrophilic Organizing Region counts and Proliferating Cell Nuclear Antigen in epithelial odontogenic tumors and to assess the usefulness of AgNOR and PCNA as markers in malignant potential of epithelial odontogenic tumors.

\section{MATERIALS AND METHODS}

The present study included 45 cases of different epithelialodontogenic tumors: 15 cases were diagnosed as keratocystic odontogenic tumor, 20 cases as ameloblastoma three cases as calcifying epithelial odontogenic tumor, two cases as adenomatoid odontogenic tumor and five cases as ameloblasic carcinoma. The cases were collected from the Cranio-Maxillofacial and Plastic Surgery Department at the Faculty of Dentistry, Alexandria University.A written informed consent was taken from all the patients.One surgical specimen was taken from tooth germ serving as negative control.The specimens were fixed in $10 \%$ neutral buffered formalin, processed and embedded in paraffin wax using the conventional procedures.Serial sections of 3-4 $\mu \mathrm{m}$ thick were placed on glass slides and stained using hematoxylin and eosin (H\&E).

AgNOR technique: Another section of each block was stained with AgNOR technique according to Plotonet al. (23)The working solution was prepared as follows: 50\% silver nitrate solution , 2 parts and gelatin solution (gelatin $2 \mathrm{~g}$, formic acid $1 \mathrm{ml}$, distilled water $100 \mathrm{ml}$ ), one part. The two solutions were mixed before use. The dewaxed sections were hydrated and rinsed in distilled water. The slides were then incubated in freshly prepared working solution for 45 minutes at room temperature, followed by rinsing in distilled water for one minute, dehydrated, cleared and mounted in DibutylPhathalate Xylene (DPX).AgNOR's were evaluated under $\times 1000$ oil immersion. AgNOR dot appeared as brownish black dots within the brown stained nucleus on a pale yellow back ground. Closely aggregated dots were counted and recorded as separate dots. The AgNOR count in 100 cells was done to get the mean number of NORs per nucleus by the Computer Image Analyzer System (Fig. 1).

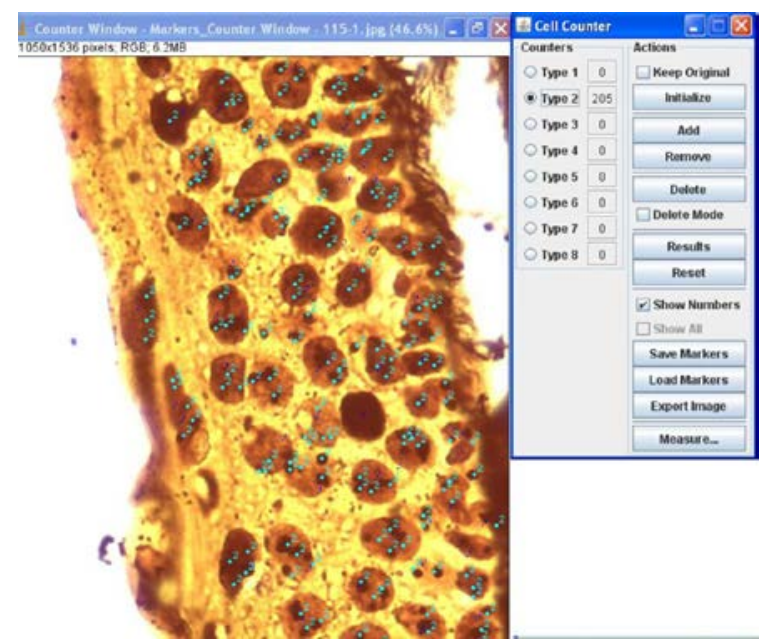

Figure 1: Calculation method with image analyzing system.

Immunohistochemical technique for PCNA: Immunohistochemical (IHC) staining for PCNA was performed to other sections using the Labeled Strept-avidin biotin complex method (LSAB). Then, the sections were examined by the image analyzer computer system using the software Leica Qwin 500. The device includes a light microscope cabled to a microcomputer that performs high speed digital image processing.

Representative fields were randomly selected in each case. These areas included only well preserved and maximum PCNA-positive epithelial areas. Clear brown nuclei were regarded as indicating PCNA positive cells. The positive cells were counted by the Computer Image Analyzer System with ( $\times 400$ magnification). For each case the cells that werepositive for PCNA in at least 1000 tumor cells were counted and a percentage of positive cells was calculated (Fig. 2).

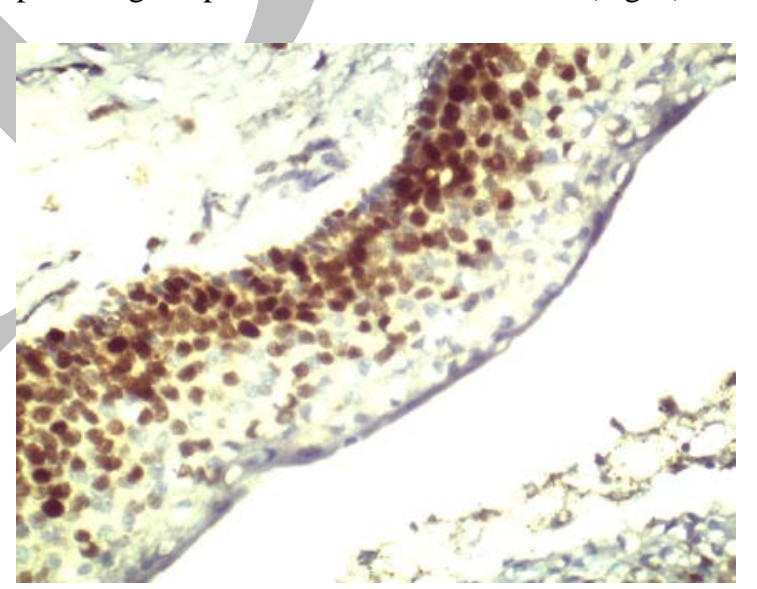

Figure 2: Keratocystic odontogenic tumor showing evident nuclear reaction of PCNA in basal and suprabasal cells (x400).

\section{Statistical analysis}

Analysis of data was performed using SPSS 17 (Statistical Package for ScientificStudies) for windows. The difference in the mean AgNOR count and percentage of PCNA positive cells for more than two groups as in different epithelial odontogenic tumors were estimated using analysis of variance (ANOVA) test.A (P) value less than 0.05 was considered highly significant. The values are given as a mean value \pm SD (standard deviation).

\section{RESULTS}

In the present work, a total of 45 patients with odontogenic tumor were included. Fifteen cases (33.3\%) were diagnosed as 
keratocystic odontogenic tumor, twenty cases (44.4\%) as ameloblastoma and three cases (6.6\%) as calcifying epithelial odontogenic tumor, two cases $(4.4 \%)$ as adenomatoid odontogenic tumorand five cases (11.1\%) as ameloblasic carcinoma.The patient's age ranged between 3 and 74 with a mean of 38 years.

Pattern of AgNORs count: Mean AgNOR count of ameloblastc Carcinoma was highest88 among the cases studied (3.12 \pm 0.2892$)$ followed by ameloblastoma $(2.27 \pm 0.0919)$ and KCOT $(1.90 \pm 0.1044)$. While mean AgNOR was the lowest in tooth germ 1.21 (Table 1 and Fig. 3).

Table 1: Mean AgNOR count of the studied cases of odontogenic tumors.

\begin{tabular}{|c|c|}
\hline 1- Odontogenic Tumor & Mean AgNOR \\
\hline Tooth Germ & 1.21 \\
\hline Conventional ameloblastoma & 2.27 \\
\hline Unicysticameloblastoma & 1.95 \\
\hline Keratocystic odontogenic tumor & 1.90 \\
\hline $\begin{array}{c}\text { Calcifying Epithelial } \\
\text { Odontogenic Tumor }\end{array}$ & 1.39 \\
\hline $\begin{array}{c}\text { Adenomatoid Odontogenic } \\
\text { Tumor }\end{array}$ & 1.31 \\
\hline Ameloblastic Carcinoma & 3.12 \\
\hline
\end{tabular}

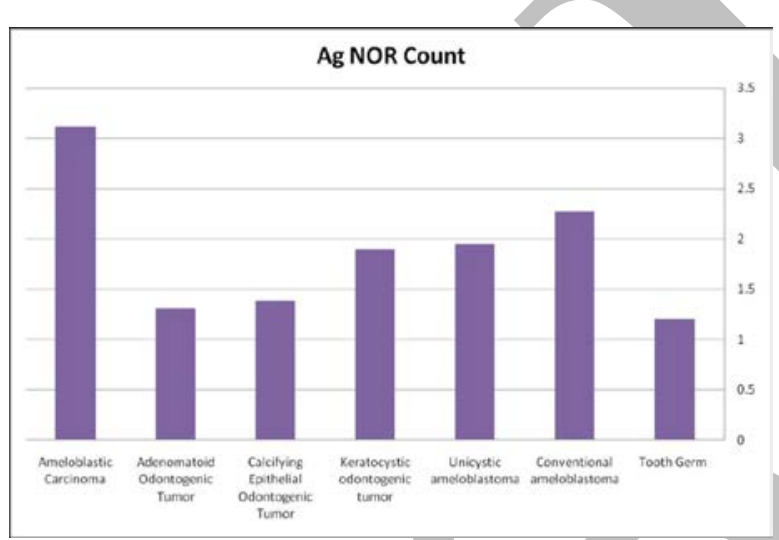

Figure 3: Mean AgNOR count of the studied cases of odontogenic tumors,

No significant difference was found between KCOT and ameloblastoma, though the mean AgNOR count of ameloblastoma was slightly higher $(P>0.05)$.

Significant difference was found between the malignant odontogenic tumor (ameloblastic carcinoma) and other benign odontogenic tumors $(P<0.01)$ indicating a highly significant Value. Ameloblastomawhen compared with AOT and CEOT, showed a highly significant difference between these two tumors $(P<0.01)$.

\section{Pattern of PCNA count}

All studied cases were immunopositive for PCNA. Overall, Tooth germ demonstrated fewer PCNA-positive cells, The highest number of PCNA-positive cells was observed in ameloblastc carcinoma (85.62\%) followed by ameloblastoma (67.06\%) and Calcifying Epithelial Odontogenic Tumor (60.9\%) while the lowest number of PCNA-positive cells was observed in Adenomatoid Odontogenic Tumor (59.57\%) and Keratocystic odontogenic tumor (57.04\%) (Table 2 and Fig. 4).
Table 2: Mean PCNA percentage of the studied cases of odontogenic tumors.

\begin{tabular}{|l|l|}
\hline \multicolumn{1}{|c|}{\begin{tabular}{c} 
1- $\begin{array}{l}\text { Odontogenic } \\
\text { Tumor }\end{array}$ \\
\hline Tooth Germ
\end{tabular}} & Mean PCNA \\
\hline Conventional ameloblastoma & $67.06 \%$ \\
\hline Unicysticameloblastoma & $63.96 \%$ \\
\hline $\begin{array}{l}\text { Keratocystic odontogenic } \\
\text { tumor }\end{array}$ & $57.04 \%$ \\
\hline $\begin{array}{l}\text { Calcifying Epithelial } \\
\text { Odontogenic Tumor }\end{array}$ & $60.9 \%$ \\
\hline $\begin{array}{l}\text { Adenomatoid Odontogenic } \\
\text { Tumor }\end{array}$ & $59.57 \%$ \\
\hline Ameloblastic Carcinoma & $85.62 \%$ \\
\hline
\end{tabular}

Figure 4: Mean PCNA percentage of the studied cases of odontogenic tumors.

\section{DISCUSSION}

Nucleolar organizer regions are the sites of ribosomal RNA synthesis that reflects protein synthesis. AgNORs that stain for NOR-associated proteins is known to increase with increase in cell ploidy, increased transcriptional activity, and in states of active cell proliferation $(5,6)$, to assess the prognosis (10-12) and also to evaluate the risk of recurrence (14).

Silver nitrate staining was used by some researchers in the differentiation of the grade of the lesions, recurrence probability and even for predicting the aggressive behavior. It should also be mentioned that most of the oral pathological studies have been done on squamous cell carcinoma (11), salivary gland tumors (12) and there were few studies done on odontogenic lesions. The histochemical technique with silver staining has been used in a number of investigations since the early 1980s for the purpose of visualizing NORs found in acrocentric chromosomes. Since its beginnings, this technique has undergone various changes under the enhanced expression of AgNORs, in an attempt to eliminate or reduce those artifacts that may interfere with viewing them (13).

The application of morphological methods to study cell proliferation is affected by various factors that can escape any observer (14). During the observation of samples in this study, background staining was detected that hindered to a certain extent the process of analysis and identification of AgNORs, which is consistent with observations described by Lindner et al (15). 
Although the AgNOR technique is described by certain authors as being simple, cost-effective and easy to perform (13, $16,17)$, it should also be taken into account that this technique is sensitive to various factors, including the thickness of histological sections, the reaction temperature of the solutions, the concentration of silver nitrate, incubation times and even the use of glass that is not perfectly clean (8). Such factors may hinder the identification of the AgNORs. Furthermore, the interpretations of these data are less reliable if not supported by a computational method.

Quantitative and qualitative changes of NORs can imply the degree of cell nucleolar activity in hyperplastic and neoplastic conditions. Actively proliferating cells have impaired nucleolar association and, therefore, exhibit a higher AgNOR count, regardless of the ploidy state of the cell (6). Histopathological studies of NORs have resulted in successful diagnosis, categorization and prognostication of various benign and malignant lesions $(10,11)$. Counting, is the most widely used method for evaluating AgNORs because of technique simplicity and reproducibility (12).

Rosa et al. found higher number of AgNORs in basal cell carcinoma than in ameloblastoma. AgNORs in basal cell carcinoma were smaller, more numerous and more widespread than in ameloblastoma, which could be anticipated considering the higher degree of cellular proliferation in basal cell carcinoma (24). In the present study, we found significant difference in the AgNOR counts in benign odontogenic tumors and ameloblastic carcinoma, AgNOR count were increasing in number and widely distributed in ameloblastic carcinoma (Fig. 5).

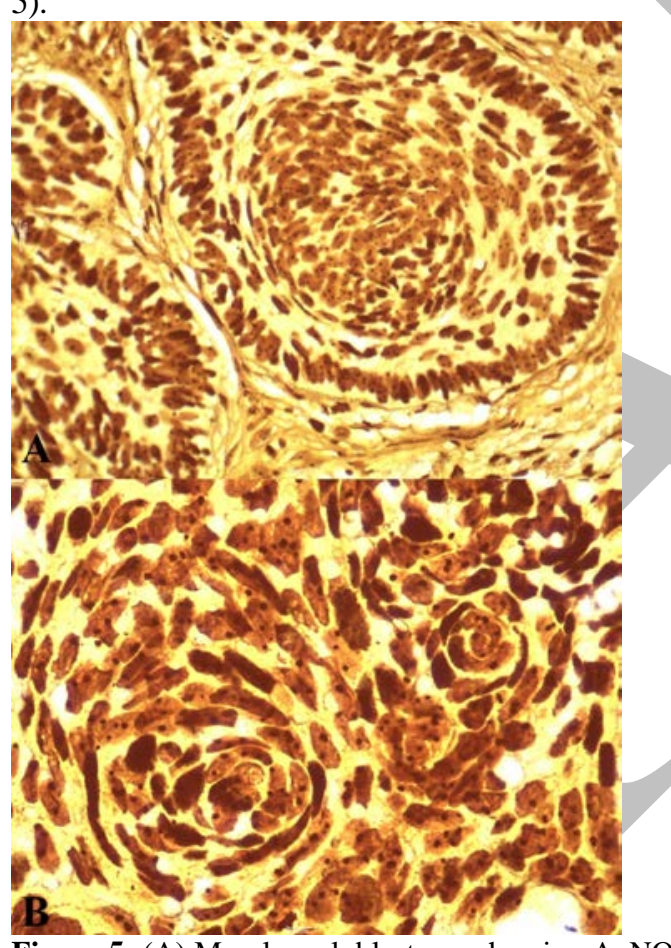

Figure 5: (A) Mural ameloblastoma showing AgNOR dots in the nuclie (x1000), (B) A case of ameloblastic carcinoma showing positive reaction of AgNOR in the nuclei of epithelial cells. (x1000).

In the present study, the number of AgNOR dots in multicystic ameloblastoma was found to be higher than those in unicystic ameloblastoma, but NORs pattern was similar in the two odontogenic tumors. Therefore, multicystic ameloblastomas have more aggressive behavior than unicystic ameloblastomas. Santos et al., reported a significant difference in the number of
AgNOR dots counted between ameloblastoma and unicystic ameloblastoma in their study (25).

While comparing multicystic ameloblastoma with AOT and KCOT, the speed of the cell cycle, proliferation activity, and metabolic activity of the cell were found to be higher in multicystic ameloblastoma. The difference in the number of the NOR dots as well as their arrangement in odontogenic lesions observed in this study reflects the differences in their biological behavior. In both unicystic and multicystic ameloblastoma, the AgNOR dots distribution was abnormal, and they were cluster shaped, irregular, and relatively small and round.

Our results also show that mean AgNOR counts are significantly higher in KCOT and ameloblastoma as compared to CEOT and AOT suggesting that these lesions have a higher proliferative capacity.

These findings are similar to previous studies which have shown higherAgNOR index in KCOT and ameloblastoma as compared to other benign odontogenic lesions $(25,26)$,and also correlate with the growth potentiality of these lesions. A higher proliferative activity in KCOT as compared to unicystic ameloblastoma has been reported previously (25).

Do Carmo and Silva found a significant difference in the number of AgNORs between adenomatoid odontogenic tumor and follicular ameloblastoma, adenomatoid odontogenic tumor and primary ameloblastoma with recurrence. Adenomatoid odontogenic tumor showed no significant difference in the number of NORs in a comparison with acanthomatous ameloblastoma, plexiform ameloblastoma, primary ameloblastoma without recurrence and recurrent ameloblastoma (26). Their results discounted a relationship between the clinical behavior of adenomatoid odontogenic tumor and ameloblastoma and their cell proliferation indices. However, in the present study, we found a significant difference in AgNOR counts of ameloblastoma and adenomatoid odontogenic tumor, reinforcing the known aggressive behavior of ameloblastoma.

In this study we used both PCNA technique and AgNOR dots count to compare the proliferative activity, as well as, the malignant potentiality of the benign lesions which have a higher risk for malignant transformation.

PCNA in ameloblastic carcinoma has been studied earlier. Kim et al., (28) in 1994 and Setsuko et al., (29) studied one ameloblastic carcinoma and reported very high PCNA values. Deeb et al., (30) studied three ameloblastic carcinomas by PCNA and AgNOR and reported that they could be used to distinguish between ameloblastoma and ameloblastic carcinoma. However, it should be noted that they studied the three cases by comparing the intensity of staining. The present study can be considered as a pioneering study, where the PCNA-positive cells in different variants of ameloblastoma and five ameloblastic carcinomas were counted.

The present study showed the maximum PCNA-positive cells in ameloblastic carcinoma specimens (Fig. 6). PCNApositive cells were found in the basal and parabasal layers as well as in the stellate reticulum areas of ameloblastic carcinoma showing follicular and plexiform patterns. The results were similar to the results of Kim et al., (28) and Setsukoet al.,(29)who studied one ameloblastic carcinoma. They reported high PCNA values in their studies and opined that PCNA values may be useful for determining the possibility of malignant transformation in recurrent cases of ameloblastoma. 


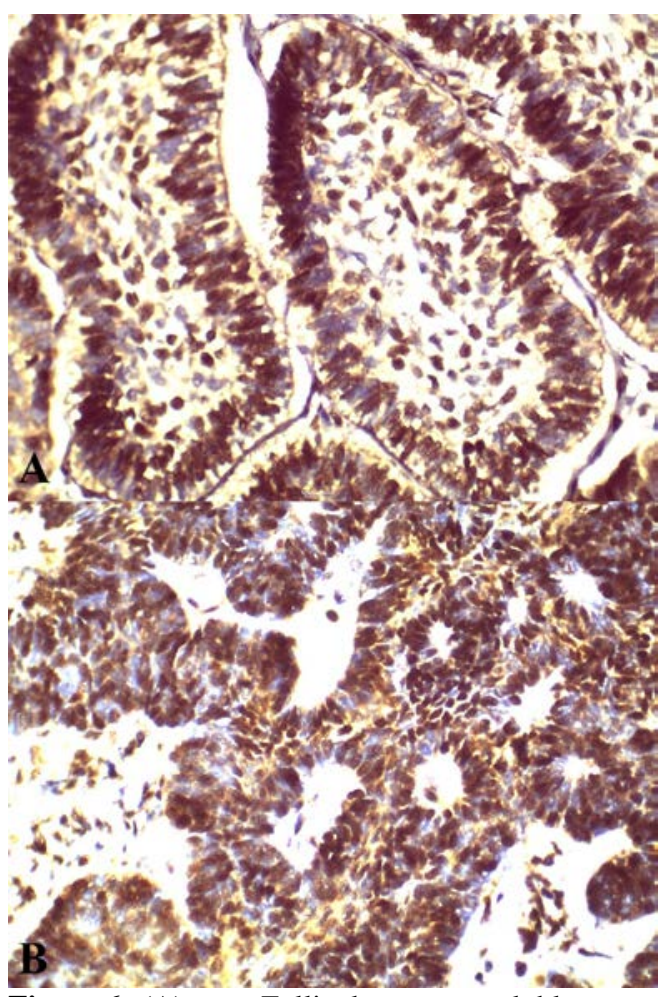

Figure 6: (A) Follicular ameloblastoma connective tissue cells (x400), (B) Ameloblastic carcinoma showing brownish reaction of PCNA in the nuclie of malignant epithelial cells (x400).

Deeb et al., (30) studied PCNA in three ameloblastic carcinomas and the variants of ameloblastoma and reported that the highest mean value of PCNA-positive cells was demonstrated in ameloblastic carcinoma followed by follicular ameloblastoma. They could not find a significant difference in the number of PCNA-positive cells between ameloblastic carcinoma and the other variants of ameloblastoma. However, in the present study, a significant difference was noted when the PCNA values of variants of ameloblastoma were compared with that of ameloblastic carcinoma separately. This difference may be attributed to the method adopted by Deeb et al.,(30)since their comparisonwas based on the difference in the percentage of cells with positive staining (classified as absent, weak, moderate and strong staining) rather than on the counts of PCNA-positive cells (the counting procedure was adopted by them only in AgNOR staining).

The least number of PCNA-positive cells was seen in unicystic ameloblastoma. This study demonstrated PCNApositive cells in the intramural tumor islands. Cystic tumor lining had relatively few PCNA-positive cells. Our results were similar to results of Funaoka et al.,(31), who reported that the cystic type showed a low positive PCNA index. It was also similar to results of Maya et al.,(32) in 2012, who reported that unicystic ameloblastoma showed lower values than ameloblastoma. Our results were however contradictory to the results of Meer et al.,(33) who reported that unicystic ameloblastomas showed significantly higher PCNA labeling indices than the solid and multicystic variants. The inconsistent result is probably due to the difference in methodology, especially the counting protocol used (34).

\section{CONCLUSION}

In conclusion, the different clinical behaviors between the odontogenic lesions with regard to their infiltrative ability are probably related to the proliferative index of their tumor cells. The AgNOR technique and PCNA technique may be considered as a good indicator of cell proliferation. Our results suggest that the cell proliferation activity is related to the greater aggressiveness of ameloblastic carcinoma in comparison with ameloblastoma and other benign odontogenic tumors.

\section{CONFLICT OF INTEREST}

The authors declare that they have no conflicts of interest.

\section{REFERENCES}

1. Regezi JA, Scuibba AJ, Jordan RC. Oral Pathology, Clinical - Correlations. $5^{\text {th }}$ ed. Philadelphia: WB Saunders; 2003. 261-81.

2. Barnes L, Eveson JW, Reichart P, Sidransky D. Pathology and Genetics of Head and Neck Tumours. Lyon: IARC Press; 2005. 284-327.

3. Neville BW, Damm DD, Allen CM, Bouquot JE. A Textbook of Oral and Maxillofacial Pathology. $3^{\text {rd }}$ ed. St. Louis: WM Saunders Co.; 2009. 701-31.

4. Reichart PA, Philipsen HP. Odontogenic Tumors and Allied Lesions. London: Quintessence Publishing Co. Ltd.; 2004.

5. Hernandez-Verdun D. The nucleolus: a model for the organization of nuclear functions. Histochem Cell Biol. 2006;126:135-48.

6. Trere D. AgNOR staining and quantification. Micron. 2000;31:127-31.

7. Eroz R, Unluhizarci K, Cucer N, Ozturk F. The Value OfArgyrophilicNucleolarOrganising Region Protein Determinations in Non-Diagnostic Fine Needle Aspiration Samples (Due To Insufficient Cell Groups) of Thyroid Nodules. Anal Quant CytopatholHistpathol. 2013;35:22631.

8. Oktay M, Eroz R, Oktay NA, Erdem H, Başar F, Akyol L, et al. Argyrophilic nucleolar organizing region associated protein synthesis for cytologic discrimination of follicular thyroid lesions. Biotech Histochem. 2015;90:179-83.

9. Eroz R, Okur M, Ozkan A, Berik O, Gunes C. Does higher NORsexpression affect the developmental stages of down syndrome infants? Genet Couns. 2012;23:249-53.

10. Smith R, Crocker J. Evaluation of nucleolar organizer region-associatedproteins in breast malignancy. Histopathology. 1988;12:113-25.

11. Hanemann JA, Miyazawa M, Souza MS. Histologic grading and nucleolar organizer regions in oral squamous cell carcinomas. J Appl Oral Sci. 2011;19:280-5.

12. Alaeddini M, Khalili M, Tirgari F, Etemad-Moghadam S. Argyrophilic proteins of nucleolar organizer regions (AgNORs) in salivary gland mucoepidermoid carcinoma and its relation to histological grade. Oral Surg Oral Med Oral Pathol Oral RadiolEndod. 2008;6:758-62.

13. Selvi B, Demirtas H, Eroz R, Imamoglu N. Investigation of the age dependent AgNOR protein level in buccal epithelial cells of healthy individuals. Aging ClinExp Res. 2015;2018.

14. Colakoglu S, Saritas A, Eroz R, Oktay M, Yaykasli KO, Akoz A, et al. Is one-time carbon monoxide intoxication harmless?Evaluation by argyrophilic nucleolar-organizing regions staining method.Hum ExpToxicol. 2015;34:24-31. 
15. Kandis H, Afacan MA, Eroz R, Colakoglu S, Bayramoglu A, Oktay M, et al. Can argyrophilic nucleolar organizing region-associated protein amount be used for the detection of cardiac damage? Hum ExpToxicol. 2015;35:1-9.

16. doCarmo MA, Silva EC. Argyrophilic nucleolar organizer regions (AgNORs) in ameloblastomasand adenomatoidodontogenictumours (AOTs). J Oral Pathol Med. 1998;27:153-6.

17. Coleman HG, Altini M, Groeneveld HT. Nucleolar organizer regions (AgNORs) in odontogenic cysts andameloblastomas. J Oral Pathol Med. 1996;25:436-40.

18. Kelman Z. PCNA: Structure, functions and interactions. Oncogene. 1997;14:629-40.

19. Giovanni M, Hubscher U. Proliferating cell nuclear antigen (PCNA); a dancer with many partner. J Cell Sci. 2003;116:3051-60.

20. Tsai ST, Jin YT. Proliferating cell nuclear antigen [PCNAI expression in oral squamous cell carcinomas. J Oral Pathol Med. 1995;24:313-5.

21. Barboza CA, Pereira Pinto L, Freitas Rde A, Costa Ade L, Souza LB. Proliferating cell nuclearantigen (PCNA) and p53 protein expression in ameloblastoma and adenomatoid odontogenic tumor. Braz Dent J 2005;16:56-61.

22. Lee JJ, Kuo MY, Cheng SJ, Chiang CP, Jeng JH, Chang $\mathrm{HH}$, et al. Higher expressions of p53 and proliferating cell nuclear antigen (PCNA) in atrophic oral lichen planus and patients with areca quid chewing. Oral Surg Oral Med Oral Pathol Oral RadiolEndod. 2005;99:471-8.

23. Ploton D, Menager M, Jeannesson P, Himber G, Piegeon F,AdnetJJ. Improvement in the staining and visualization of theargyrophilicproteins of the nucleolar organizer regions at theoptical level.Histochem J. 1986;18:5-14.

24. Rosa LE, Jaeger MM, Jaeger RG. Morphometric study of nucleolar organizer regions in ameloblastoma and basal cell carcinoma. Oral Oncol. 1997;33:209-14.

25. Santos AC, Chaves Tarquinio SB, Riet Correa Rivero E, Maria Aver Araujo L, Lorio Krause C. Quantitative AgNORs Study in ameloblastoma. Rev OdontolCienc. 2009;24:10-4.

26. Selvi F, Tekkesin MS, Cakarer S, Isler SC, Keskin C. Keratocystic odontogenic tumors: Predictive factors of recurrence by Ki-67 and AgNOR labelling. Int J Med Sci. 2012;9:262-8.

27. Do Carmo MA, Silva EC. Argyrophilic nucleolar organizer regions in ameloblastomas and adenomatoidodontogenic tumour (AOTs). J Oral Pathol Med. 1998;27:153-6.

28. Kim J, Yook JI. Immunohistochemical study on proliferating cell nuclear antigen expression in ameloblastomas. Eur J Cancer B Oral Oncol. 1994;30:12631.
29. Setsuko H, Masanobu S, Yaeko N, Hiroki M, Keigo K. An autopsy case of Malignantameloblastoma in maxilla: A case study. Oral Med Pathol. 1999;4:39-43.

30. El Deeb A, Moustafa WA. Expression of cell proliferation markers (PCNAand AGNOR) inodontogenic cysts and ameloblastoma Official Journal of the Egyptian Dental Association; 2003.

31. Funaoka K, Arisue M, Kobayashi I, Iizuka T, Kohgo T, Amemiya A,et al. Immunohistochemical Detection of Proliferating Cell Nuclear Antigen (PCNA) in 23 Cases of Ameloblastoma. Oral OncolEur J Cancer. 1996;32:328-32.

32. Maya R, Sekar B, Murali S. Comparative evaluation of expression of proliferating cell nuclear antigen in variants of ameloblastoma and ameloblastic carcinoma. Indian J Dent Res. 2012;23:15-9.

33. Meer S, Galpin JS, Altini M, Coleman H, Ali H. PCNA and Ki 67immuno reactivity in ameloblastomas. Oral Surg Oral Med Oral Pathol Oral RadiolEndod. 2003;95:213-21. 